\title{
AMPLA DEFESA E CONTRADITÓRIO: ANÁLISE DA PRECLUSÃO NO VIGENTE SISTEMA PROCESSUAL
}

\section{LEGAL DEFENSE AND ADVERSARIAL PRINCIPLE: ANALYSIS OF PRECLUSION IN THE CURRENT PROCESSUAL SYSTEM}

\begin{abstract}
Luiz Manoel Gomes Júnior Doutor e mestre em Direito pela Pontifícia Universidade Católica de São Paulo. Professor Titular do Programa de Mestrado em Direito da Universidade Paranaense (Paraná) - UNIPAR e no Programa de Doutorado e Mestrado em Direito da Fundação Universidade de Itaúna

(Minas Gerais) - UIT.

Edison França Lange Júnior

Mestrado do Programa de Pós-Graduação em Processo e Cidadania da Universidade Paranaense - UNIPAR. Docente na UNIGRAN. Servidor do Tribunal de Justiça de Mato Grosso do Sul.

RESUMO: No presente artigo, busca-se desenvolver a noção do sistema preclusões à luz dos princípios do contraditório e ampla defesa, mediante uma análise da função dos institutos voltada ao processo justo, avaliando, neste contexto a sistemática da resposta do réu no Novo Código de Processo Civil. Para tanto, fez-se necessário o estabelecimento de uma concepção material do contraditório, analisando os efeitos jurídicos concretos inerentes a essa nova perspectiva. Foi utilizado para a pesquisa o método dedutivo, através da análise bibliográfica e jurisprudencial sobre o tema.
\end{abstract}

PALAVRAS-CHAVE: Contraditório; Defesa; Preclusão; Resposta; Dialética

ABSTRACT: In this article, we seek to develop the notion of the system preclusions in the light of the principles of the adversary and legal defense, through an analysis of the function of the institutes focused on the fair process, evaluating, in this context, the systematic of the defendant's response in the New Process Code Civil. For that, it was necessary to establish a material conception of the adversary, analyzing the concrete legal effects inherent to this new perspective. The deductive method was used for research, through bibliographic and jurisprudential analysis on the topic.

KEYWORDS: Contradictory; Defense; Preclusion; Response; Dialectic

\section{INTRODUÇÃO}


O Código de Processo de Civil de 2015, instituído pela Lei Federal n ${ }^{\circ}$ 13.105/2015, estabeleceu como norma fundamental o princípio da boa-fé processual, consoante previsão do art. $5^{\circ}$, caput. Portanto, trata-se de princípio geral que deve nortear a atuação de todos os participantes no processo civil, servindo de limitação a prática de atos cujo objetivo principal seja o exercício abusivo de direitos processuais.

Pretende-se à análise da possibilidade de reconhecer atos realizados no curso processual, como transgressores da boa-fé processual, ainda que não especificamente definidos pelo Código de Processo Civil, como: litigância de má-fé, atentatório a dignidade da justiça ou fraude à execução, com olhos voltados especificamente no seio das demandas executivas, tanto nas execuções autônomas como na fase de cumprimento de sentença.

Especificamente no campo da execução civil, o Código de Processo Civil muito se preocupa em capitular atos como litigância de má-fé, atentatórios a dignidade da justiça ou fraudulentos, voltados a reprimir atos praticados pelo executado, possivelmente, por presumir que este teria maior interesse em causar prejuízos ao exequente, no que consiste a realização de medidas para obstruir o andamento processual ou simplesmente dificultar o acesso a seus bens, inevitáveis para o cumprimento da obrigação devida.

Com isso, a jurisprudência é reticente na aplicação do princípio da boa-fé, como fundamento para reconhecer atos abusivos e lesivos praticados pelo exequente no curso das demandas executivas, visando impor condições mais gravosas ao executado, ou até mesmo, dificultar o exercício do direito de defesa, o que também configuraria violação ao princípio do acesso à justiça, contraditório e ampla defesa.

Portanto, imprescindível para a compreensão do tema, reconhecer que a positivação da boa-fé como norma fundamental do processo civil, criou padrões de conduta que devem ser observados por todos os sujeitos processuais, sob pena do reconhecimento da abusividade, ainda que não especificamente definido com tal característica.

Para consecução dos objetivos pretendidos neste artigo, voltou-se a pesquisa bibliográfica específica, por meio de obras atualizadas de acordo com o vigente Código de Processo Civil, além da análise das disposições pertinentes e, por fim o entendimento jurisprudencial.

\section{PRINCÍPIO FUNDAMENTAL DA BOA-FÉ PROCESSUAL}


Após a promulgação da Constituição da República Federativa do Brasil de 1988, iniciouse a constitucionalização do direito, sendo que as relações jurídicas (pública e privada) passaram a exigir respeito as normas e princípios que estabelecem direitos fundamentais, entre as quais, cita-se a dignidade da pessoa humana, solidariedade, igualdade, além dos princípios constitucionais específicos que se aplicam ao processo civil.

Até a entrada em vigor da Lei $n^{\circ} 13.105 / 2015$, que instituiu o vigente Códigode Processo Civil Brasileiro, o processo era regido pelo Código de Processo Civil de 1973 (Lei n ${ }^{\circ}$ 5.869/1973), diploma normativo estatuído com a preocupação precípua de resolver litígios meramente patrimoniais, cujo foco não estava na persecução dos direitos fundamentais.

O Código de Processo Civil, não alheio a onda de constitucionalização do direito, logo na sua parte geral, sob a denominação de normas fundamentais do processo civil, elencou expressamente uma série de princípios constitucionais ou deles derivados, como norteadores do processo civil brasileiro, enunciando no art. $1^{\circ}$ que "O processo civil será ordenado, disciplinado e interpretado conforme os valores e as normas fundamentais estabelecidos na Constituição Federal de 1988, além das disposições do CPC”.

Portanto, comentando sobre o artigo $1^{\circ}$ do CPC/2015, Luiz Guilherme Marinoni reconhece que o processo civil está estruturado a partir dos direitos fundamentais que compõem o direito fundamental ao processo justo, entendendo, ainda, que "as dúvidas interpretativas devem ser resolvidas a favor da otimização do alcance da Constituição e do processo civil como meio de tutela dos direitos" (MARINONI, 2019, p. 168).

Entre essas normas fundamentais, houve a positivação da boa-fé processual, expressa no art. $5^{\circ}$ do $\mathrm{CPC} / 2015$, dispondo que "Aquele que de qualquer forma participa do processo deve comportar-se de acordo com a boa-fé" (BRASIL, 2015).

Ao situar a boa-fé entre as normas fundamentais do processo civil brasileiro, o legislador erigiu um mandamento que deve ser seguido e aplicado por todos os sujeitos processuais, dele extraindo todos os efeitos possíveis, ou seja, conforme lições de Robert Alexy, ao tratar da aplicação dos princípios fundamentais, reconhece que este deve ser "realizado na maior medida possível dentro das possibilidades jurídicas e fáticas existentes. Princípios são, por conseguinte, mandamentos de otimização" (ALEXI, 2019, p. 90).

Não sem razão, sustenta Fabio Caldas de Araújo que o princípio da boa-fé no processo civil, destina-se a função interpretativa, integradora e corretiva da relação

processual, complementando o autor que "Sem o princípio da boa-fé a relação processual 
legitimaria condutas inapropriadas e sem limites. Não devemos esquecer que o processo reflete uma batalha entre as partes, mas com estratégias e atos que devem se pautar pela lealdade“ (ARAÚJO, 2016, p. 187).

Portanto, dado o caráter de generalidade da norma fundamental que institui a boa-fé processual, esta deve influenciar todo o ordenamento processual, desde a postulação até a prolação da sentença e, dirigida a todos aqueles que atuam no processo de natureza cível (Enunciado 378 do FPPC).

\section{PRINCÍPIO DA BOA-FÉ NAS DEMANDAS EXECUTIVAS}

O processo executivo em sentido amplo, compreendendo a execução autônoma e o cumprimento de sentença, são regidos por princípios próprios, que podemos citar os princípios da nulla executio sine titulo, da responsabilidade patrimonial, da menor onerosidade e etc.

Entretanto, ao traçar os parâmetros de aplicação do princípio da boa-fé aos processos executivos, a doutrina ainda permanece inclinada em vinculá-los somente aos atos praticados pelo executado, tanto que Fredie Didier Junior, ao analisar a aplicação da boa-fé, pondera que a ação executiva é um dos ambientes mais propícios para a prática de comportamentos desleais, abusivos ou fraudulentos, observando que a aplicação do princípio se destina ao combate à prática "da fraude contra credores, fraude à execução e a punição aos atos atentatórios à dignidade da justiça" (DIDIER JR., 2017, p. 68), ou seja, atos geralmente praticados pelo executado.

Afora esse entendimento, as ações executivas comportam a realização de atos abusivos, transgressores da boa-fé processual, praticados pelo exequente, cujo intuito extrapola sua pretensão de apenas ver satisfeito seu crédito junto ao devedor.

Basta reconhecer que há uma superioridade da posição processual exercida pelo exequente, isso porque, em favor dele milita a presunção de legitimidade do direito invocado, sendo os atos processuais, inclusive expropriatórios, exercitados através de cognição mitigada. Em razão disso, Fabio Caldas de Araújo anota haver nas demandas executivas, predominância da prática de atos executivos que atuam na esfera concreta, praticados sem qualquer manifestação do executado que integra a relação processual (ARAÚJO, 2016, p. 114).

Não alheio a essa posição de superioridade do exequente, o art. 776 do CPC/2015, traz norma de responsabilidade objetiva, atribuindo responsabilidade ao exequente na reparação de eventuais danos causados ao executado, quando a sentença (transitada em julgado) declarar 
inexistente a obrigação que ensejou a execução.

Com isso, pretendemos concluir que os atores processuais (nas demandas executivas) não devem ficar atrelados a ideia de atuação da boa-fé ou má-fé apenas nos casos previstos em lei, cabendo destacar o entendimento de Cassio Scarpinella Bueno, no sentido de que o art. $5^{\circ}$ do CPC/2015, deve conduzir o intérprete a caminhos diversos, não apenas aos casos tipificados pelo código, devendo, no mínimo, os institutos processuais que envolvam a aplicação da boafé/má-fé, serem fortalecidos e robustecidos, sendo reanalisados na perspectiva da cláusula geral insculpida no art. $5^{\circ}$ (BUENO, 2020, p. 407).

\section{VIOLAÇÃO DA BOA-FÉ PELO EXEQUENTE}

Normalmente o processo executivo não evolui ou é eficaz na satisfação do interesse do credor, em razão de atos praticados pelo executado, que acintosamente, age criando meios para retardar a marcha processual e muitas vezes impedir o alcance do direito pelo exequente. Esse cenário é o que ocorre na maioria das vezes nos processos executivos em geral, nas espécies de cumprimento sentença e execuções autônomas por título judicial ou extrajudicial.

Trata-se de decorrência do entendimento anteriormente ressalvado, de que o princípio da boa-fé se presta a possibilitar uma jurisdição justa e efetiva, exigindo atuação éticas, com respeito aos limites jurídicos e morais no exercício do direito, que também asseguram o acesso à justiça.

Ocorre que, não raras vezes é o próprio exequente quem pratica atos eivados de má-fé ou ao menos abusivos, tendentes a dificultar a defesa do executado, ou mesmo tornar o cumprimento da obrigação ainda mais dificultosa para o devedor. Não se pode esquecer que em determinados casos concretos, a desigualdade entre as partes é gigantesca, tanto na esfera econômica, social e técnica, o que estimularia a realização de abusos processuais pelo exequente, no intuito de prejudicar o executado.

Nas demandas executivas a má-fé também está vinculada ao que se denomina abuso de direito, presente nas situações de exercício irregular de um direito, cujo escopo reside não na obtenção ou satisfação de um direito próprio, mas na verdade em imputar um sacrifício maior ao direito alheio, nesse caso ao executado.

Além da obediência ao princípio fundamental da boa-fé objetiva processual ( $\operatorname{art} .5^{\circ}$ do CPC), o exequente deve agir pautado dentro dos limites do exercício de umdireito, sob pena de 
incidir em ato ilícito, conforme cláusula geral prevista no art. 187 do Código Civil.

Segundo José Ricardo Alvarez Vianna a boa-fé exerce papel relevante para que o processo seja meio de prestação jurisdicional efetiva e justa, exigindo dos sujeitos processuais, condutas em conformidade com os preceitos de natureza éticas, de modo a fazer respeitar os limites jurídicos e morais no exercício do direito constitucional de acesso à justiça (VIANA, 2018, p. 17-37). O citado autor faz duas conclusões, que "a litigância de má-fé nada mais é do que uma espécie do abuso de direito" e "seria até desnecessária a previsão específica da litigância de má-fé no Código de Processo Civil", reconhecendo que a reprovação e reprimenda são consectários do abuso de direito(2018, p 17-37).

$\mathrm{Na}$ mesma senda, em trabalho voltado a análise da colaboração no processo civil, os ensinamentos de Daniel Mitidiero apontam que a força normativa da boa-fé no processo civil, deve ser entendida a partir de no mínimo quatro grupos de casos, entre os quais "a proibição de abuso dos poderes processuais (por exemplo, vedação ao exercício desequilibrado do direito)", cujo fundamento para referida vedação, é extraído do dever geral de boa-fé, previsto no art. $5^{\circ}$ do CPC/2015 (MITIDIERO, 2019. p. 95).

A partir dessas premissas, os juízes e tribunais pátrios não podem dar interpretação restritiva ao princípio da boa-fé processual, que orienta o processo civil brasileiro contemporâneo, incorrendo na necessidade de reconhecimento de atos processuais abusivos ou violadores da boa-fé, ainda que não especificamente capitulados como litigância de má-fé, sob pena de esvaziamento do sentido da norma extraída do princípio fundamental da boa-fé processual.

\section{CASOS ESPECÍFICOS DE VIOLAÇÃO DA BOA-FÉ OU ABUSO PROCESSUAL PELO EXEQUENTE}

O processo executivo destina-se precipuamente a satisfação do direito do exequente. Todavia, a atividade jurisdicional realizada no processo de execução é pautada por alguns princípios específicos, destinados a proteção do executado, eis que, na forma como dito anteriormente, o exequente encontra em posição de superioridade ao adversário, derivado das características que cercam o título executivo e, importam no reconhecimento da cognição mitigada para realização de atos processuais concretos, na maioria das vezes de natureza expropriatória.

O exequente possui o dever de expor os fatos em juízo de acordo com a verdade e, não 
formular pretensão quando ciente que são destituídas de fundamento, segundo incisos I e II do art. 77 do CPC/2015.

Além do mais, também responderá o exequente por perdas e danos, caso atue com infração às condutas tipificadas como litigância de má-fé (art. 80, I a VII do CPC/2015), em especial as previstas nos incisos I a III, que vedam: a) deduzir pretensão ou defesa contra texto expresso de lei ou fato incontroverso; b) alterar a verdade dos fatos; e c) usar do processo para conseguir objetivo ilegal.

Entre os princípios específicos da demanda executiva, encontra-se a menor onerosidade da execução, com previsão legal no art. 805, caput do CPC/2015, expressando que "Quando por vários meios o exequente puder promover a execução, o juiz mandará que se faça pelo modo menos gravoso para o executado".

Analisando o referido dispositivo legal, a doutrina de Fredie Didier Junior entende que se trata de uma cláusula geral, que visa impedir o abuso do direito pelo exequente (DIDIER JR., 2017, p. 78).

Complementa o citado autor, aduzindo que:

\begin{abstract}
O princípio visa impedir a execução desnecessariamente onerosa ao executado; ou seja, a execução abusiva. Em vez de enumerar situações em que a opção mais gravosa revelar-se-ia injusta, o legislador valeu-se, corretamente, de uma cláusula geral para reputar abusivo qualquer comportamento do credor que pretender valer-se de meio executivo mais oneroso do que outro igualmente idôneo à satisfação do seu crédito (...) Trata-se de aplicação do princípio da boa-fé processual (art. $5^{\circ}, \mathrm{CPC}$ ) (DIDIER JUNIOR, 2017, p. 78).
\end{abstract}

Entendendo possuir propriedades de cláusula geral, há possibilidade de reconhecimento de situações abusivas praticadas pelo exequente, ainda que não definida previamente pelo legislador como tal, ou mesmo que não se configura um caso típico de litigância de má-fé.

Deste modo, autoriza-se com base no princípio da menor onerosidade da execução, o reconhecimento de diversos atos processuais praticados pelo exequente, como violadores da boa-fé e, por conseguinte abusivos, ou até mesmo, podendo-se enquadrá-lo como litigância de má-fé, caso haja a mínima subsunção a um tipo previsto no art. 80 do CPC/2015.

\title{
5.1 POSTULAÇÃO INFUNDADA OU ABUSIVA DE ADOÇÃo DE MEIOS EXECUTÓRIOS ATÍPICOS
}

A utilização de meio executórios atípicos, com previsão no art. 139, IV e art. 536, $\S 1^{\circ}$ 
do CPC/2015, sem dúvida alguma é um dos cenários mais propícios ao exercício arbitrário de posições jurídicas por parte do exequente, o que configura manifesta violação ao princípio da boa-fé processual, podendo, inclusive, gerar grandes repercussões negativas ao executado, levando-se em conta as consequências advindas dos meios executórios atípicos, que repercutem em esferas sensíveis do demandado, geralmente impossibilitando o exercício de direitos fundamentais, entre as quais podemos citar os direitos sociais, liberdade, locomoção e etc.

A jurisprudência, com base no dispositivo legal acima citado, tem reconhecido a possibilidade de apreensão de passaporte, suspensão da carteira nacional de habilitação, bloqueio de cartões de créditos, entre outras medidas coercitivas. Todavia, a utilização desmedida dos meios executivos atípicos, em especial quando não se mostrar eficaz para satisfação dos interesses do exequente, configura-se sanção processual, conforme reconhecido pelo Superior Tribunal de Justiça (RHC 97.876/SP).

O processo executivo tem por escopo a satisfação da dívida mediante expropriação de bens do devedor, deste modo, a adoção de medidas executivas atípicas quando demonstrada a inexistência de bens do executado, suficientes para satisfação do débito, afigura-se abusiva e inócua, isso porque não interferem diretamente no resultado da demanda.

$\mathrm{O}$ art. 139, IV, revela que caberá ao juiz a determinação das "medidas indutivas, coercitivas, mandamentais ou sub-rogatórias necessárias para assegurar o cumprimento de ordem judicial, inclusive nas ações que tenham por objeto prestação pecuniária".

Por força do art. $8^{\circ}$ do CPC/2015, temos que "ao aplicar o ordenamento jurídico, o juiz atenderá aos fins sociais e às exigências do bem comum, resguardando e promovendo a dignidade da pessoa humana e observando a proporcionalidade, a razoabilidade (...)".

Todavia, para possibilitar a determinação das medidas executivas atípicas, o juiz deve ser provocado pelo exequente, que deverá apresentar suas razões de fato e de direito, hábeis a ensejar a adoção das medidas executivas atípicas, cujo intento deverá ser efetivamente a satisfação de seu crédito, e não a imposição de consequências mais gravosas ou prejudiciais ao executado.

Nessa senda, os atos do exequente tendentes a induzir o juiz na aplicação de meios executórios atípicos, quando infundada de razões fáticas e jurídicas, devem ser cabalmente afastados pelo Poder Judiciário, eis que, não visa compelir o executado a satisfazer a obrigação, mas sim impor-lhe maiores prejuízos com repercussões negativas para o exercício de outros direitos que lhes são caros.

A luz desse entendimento, a pretensão do exequente deve ser reconhecida como abusiva, 
podendo até mesmo, a depender das situações apresentadas no caso concreto, caracterizada como litigância de má-fé, o que lhe importará a aplicação de sanção pecuniária.

Também nessa situação, para o reconhecimento da abusividade ou má-fé do exequente, vale-se da aplicação conjunta dos arts. 5, caput e 805, ambos do CPC/2015.

Por isso, escreve Fredie Didier Junior, que o princípio da menor onerosidade da execução, visa proteger a boa-fé, impedindo que o exequente abuse de seu direito na cobrança de seu crédito, lançando mão de meios executivos mais danosos ao executado. $\mathrm{O}$ autor finaliza o entendimento, aduzindo que o princípio da menor onerosidade "protege a ética processual, a lealdade, impedindo o comportamento abusivo do exequente. Trata- se de aplicação do princípio da boa-fé processual (art. $5^{\circ}$, CPC) ((DIDIER JUNIOR, 2017, p. 80).

\subsection{PLEITO DE PAGAMENTO DE VERBAS INDEVIDAS}

Ao exequente, também incide o dever de postular em juízo aquilo que realmente lhe é devido. Qualquer pretensão que extrapole o direito que efetivamente lhe cabe, deve ser reprimido pelo Poder Judiciário.

Nesse sentido, o Tribunal de Justiça do Estado de São Paulo, aplicou multa em desfavor do exequente que insistiu na cobrança de valores indevidos, conforme decidido no Agravo de Instrumento $\mathrm{n}^{\mathrm{o}}$ 2123237-42.2020.8.26.0000:

CUMPRIMENTO DE SENTENÇA. Decisão que acolheu a impugnação, impôs multa por litigância de má-fé ao autor e o condenou ao pagamento de honorários de sucumbência. Manutenção. Multa bem imposta. Exequente que, apesar de alertado, insistiu na cobrança de valores indevidos, ciente de que não integravam o montante a ser restituído. Decaimento mínimo do impugnante. Sucumbência adequadamente fixada, nos termos do artigo $85, \S 2^{\circ}$, do CPC. Recurso não provido (TJSP, 2020).

O processo em análise, cuidava de ação de indenização, em que o autor (exequente da fase de cumprimento de sentença) não questionou na inicial qualquer ilegalidade no pagamento de valores a título de corretagem (em favor de terceiro), mas apenas questionava a abusividade de determinada cláusula contratual. Posteriormente, insistiu na restituição dos valores a título de corretagem, sendo alertado pelo juízo que esses valores não constavam na sentença.

Diante da insistência do exequente no recebimento de valores indevidos, houve o reconhecimento da litigância de má-fé. 
Além da violação da boa-fé nesse caso concreto, ensejou a imputação de multa por litigância de má-fé, o fato de que o processo não pode ser utilizado com a finalidade de obter algo destituído de legalidade ou fundamento.

\title{
5.3 OUTROS ATOS PRATICADOS PELO EXEQUENTE RECONHECIDOS COMO LITIGÂNCIA DE MÁ-FÉ
}

Em decisões recentes, o Tribunal de Justiça do Estado de São Paulo reconheceu alguns atos praticados pelo exequente, como litigância de má-fé.

Por exemplo, em ação de alimentos, o Tribunal de Justiça de São Paulo reconheceu a litigância de má-fé do exequente que ajuizou ação de alimentos, após a celebração de acordo exonerando o devedor do pagamento alimentar, conforme Apelação Cível nº AC 001276102.2019.8.26.0001:

\begin{abstract}
ALIMENTOS. Ação de execução. Sentença de extinção. Insurgência da exequente. Prazo prescricional que flui a partir da data em que a exequente completou a maioridade civil em 12.05.2015. Execução ajuizada em 29.06.2019. Prescrição das parcelas vencidas até 2 anos antes do ajuizamento. Art. 197, II; 198, I e 206, § $2^{\circ}$ do Código Civil. Existência de acordo que homologou a exoneração do dever alimentar a partir de fevereiro/2018. Pensão alimentícia descontada diretamente na folha de pagamento do executado. Quitação do débito demonstrada. Exequente que deduziu pretensão contra fato incontroverso. Multa por litigância de má-fé. Arts. 80, I e 81 do CPC. Sentença mantida. Recurso desprovido. (TJSP, 2019).
\end{abstract}

Nesse caso, o Tribunal reconheceu que o exequente deduziu pretensão contra fato incontroverso. Em outro julgado (Agravo de Instrumento $\mathrm{n}^{\mathrm{o}}$ 2092667- 73.2020.8.26.0000), o TJSP teve o mesmo posicionamento:

CUMPRIMENTO DE SENTENÇA. Condenação da exequente por litigância de máfé. Cabimento. Recorrente que deduziu pretensão contra fato incontroverso, sendo, ainda, nítida a sua intenção de alterar a verdade dos fatos com propósito de induzir o juízo a erro e alcançar vantagem que sabia ser indevida. Comportamento incompatível com a boa-fé processual, revelando-se correta a aplicação de sanção por litigância de má-fé. Redução, todavia, do valor da multa arbitrada. Observância dos princípios da razoabilidade e da proporcionalidade. Recurso provido em parte. (TJSP, 2020).

Questão interessante ocorreu no Agravo de Instrumento nº 2151065- 13.2020.8.26.0000, que tratava de ação de despejo por falta de pagamento cumulada com cobrança, que se encontrava em fase de cumprimento de sentença, visando o despejo do locatário, que mesmo após intimado para desocupar o imóvel, não o fez, informando ao oficial de justiça a renovação 
do contrato.

Posteriormente, os locadores postularam pela expedição de mandado para despejo coercitivo. Na sequência o locatário "antes que fosse cumprido o novo mandado, o réu e ora agravante noticiou a celebração de novo contrato entre as partes em data anterior ao requerimento de despejo, com cópia do instrumento, e pediu a aplicação da penalidade por litigância de má-fé aos demandantes".

Constou no voto do relator que o novo contrato de locação foi celebrado entre as partes após o trânsito em julgado da sentença, mesmo assim os locadores (agravados) insistiram no despejo, ainda que não houvesse controvérsia quanto à efetiva celebração do novo contrato, nem notícia de inadimplemento.

Outrossim, reconheceu-se que se os locadores não quisessem a permanência do locatário, não deveriam entabular novo contrato de locação, pois já existia sentença com trânsito em julgado com rescisão da locação anterior e ordem de despejo. O que não poderiam fazer era entabular novo contrato, não comunicar esse fato ao juízo e ainda requerer o despejo porque não mais queriam o locatário. Evidente a má fé processual.

Concluiu o acordão, reconhecendo que:

Omitir essa realidade e pedir o despejo caracteriza sim má fé. Ainda mais depois de revelada a situação insistir no despejo ao argumento de não querer o inquilino. A execução da sentença perdeu o objeto; desapareceu o interesse processual na fase de execução, o que implicaria na própria extinção do processo de execução e não o simples arquivamento.

Por fim, encontramos decisão do TJSP no Agravo de Instrumento $\mathrm{n}^{\mathrm{o}}$ 212747337.2020.8.26.0000, cujo recurso originário de um cumprimento de sentença em ação de cobrança, cuja sentença havia condenado os executados ao pagamento da quantia de $\mathrm{R} \$ 70.000,00$ mais encargos. Na fase de cumprimento de sentença, houve a determinação de correção dos cálculos, o que não foi aceito pelo exequente, que interpôs agravo de instrumento. O citado recurso não foi provido. Após, houve a retificação dos cálculos, com a devida homologação, afastando, portanto, os cálculos apresentados pelo exequente.

Mais uma vez, inconformado o exequente, interpôs embargos de declaração, com fundamento em omissões, além da repetição dos mesmos argumentos insertos no agravo de instrumento. O Juízo de primeiro grau, acolheu em parte os embargos e aplicou multa de 5\% sobre o valor da causa, por má-fé do embargante (exequente), com fundamento na deliberada insistência em reavivar argumentos cuja apreciação já se esgotou, causando 
tumulto processual.

Esse último julgado, deixa claro que o exequente pode violar a boa-fé, constando no acórdão, ainda:

(...) que suscite não ter intenção protelatória, já que seu interesse seria o prosseguimento célere da execução, seu comportamento reiterado de inconformismo quanto ao cômputo dos juros e tese de tratamento desigual às partes resulta em tumulto processual decorrente de resistência injustificada ao andamento do processo, além de configurar atuação processual temerária.

Verifica-se na análise dos julgados, que as decisões do Tribunal de Justiça do Estado de São Paulo, proferidas nos anos de 2019 e 2020, ou seja, na vigência do Código de Processo Civil de 2015, reconhecem atos como litigância de má-fé pelo exequente, contudo, ainda carecem de uma abordagem ou fundamentação, específica com fulcro do art. $5^{\circ}$ do novo Código de Processo Civil.

Não se observou nos julgados analisados e em pesquisas no TJSP, o reconhecimento de atos como violadores da boa-fé processual, considerando, portanto, abusivos com aplicação de penalidade por litigância de má-fé, com esteio apenas no art. $5^{\circ}$ do CPC/2015, sempre devendo ser vinculada a determinado caso de litigância de má- fé.

\section{POSSÍVEIS INCENTIVOS LEGAIS AO RECONHECIMENTO DA LITIGÂNCIA DE MÁ-FÉ OU ATOS ABUSIVOS}

Inobstante a boa-fé tenha importância para a eticidade de todo o sistema jurídico, a prática forense não tem revelado o seu pleno reconhecimento, na medida em que, comparando-se ao elevado número de processos judiciais em trâmite no Brasil, em termos percentuais, há um número mínimo de processos em que houve a aplicação do princípio da boa-fé processual (art. $5^{\circ}$ do CPC/2015) e, por conseguinte, o reconhecimento da litigância de má-fé ou da prática de atos processuais abusivos.

Na verdade, desde o Código de Processo Civil revogado, os juízes e tribunais (Regionais Federais e Tribunais de Justiça) atuam de forma conservadora no que tange ao reconhecimento da litigância de má-fé, considerando que nesse diploma processual, em sua redação original (posteriormente reformada pela Lei $\mathrm{n}^{\circ}$ 8.952/1994) havia necessidade da parte lesada, requerer o reconhecimento da litigância de má-fé, o que deveria ser feito com base em arguição de fatos 
coerentes sustentados por provas hábeis a demonstrar a prática do ato abusivo ou de eivado de má-fé (art. 18, caput do CPC/1973).

Por outro lado, em sede dos Tribunais Superiores, a justificativa para o não reconhecimento da litigância de má-fé e/ou atos abusivo, reside na impossibilidade que impera a esses tribunais, de realizarem o reexame da prova (AgInt no REsp 1644759/SP), tema inclusive pacificado pela Súmula 7/STJ.

Assim, resta as partes através de seus advogados, manifestarem-se de forma eficaz e, devidamente lastreadas em provas hábeis, possibilitando que os juízes no exame probatório, possam ter meios suficientes para o reconhecimento da litigância de má-fé, certos de que nessa seara, impera a presunção de que as partes agem de boa-fé.

Estando inserido entre as normas fundamentais do processo civil, a boa-fé deve ser efetivamente aplicada visando o atingimento dos objetivos primordiais do processo civil, assim, para conferir efetividade ao processo, deve ser afastada os requisitos da aplicação da boa-fé na esfera do direito material, ou seja, o direito privado não pode influenciar sobremaneira, as normas processuais, que possuem natureza de direito público.

Em doutrina específica sobre a litigância de má-fé e lealdade processual (produzida sob a égide do CPC/1973), Celso Hiroshi Iocohama fez crítica a redação original do art. 18 do CPC/1973, bem como, deixou claro que a litigância de má-fé e o abuso processual, produzem efeitos nefastos a todos os envolvidos no processo, inclusive aos "serviços jurisdicionais", conforme indagação no seguinte sentido:

\footnotetext{
Evidentemente, o magistrado acabava deparando-se com um problema incoerente: se a má-fé provocava não somente prejuízos à parte adversa, mas principalmente aos serviços jurisdicionais, atrasando-os, induzindo-os ao erro e provocando atividades inúteis, parecia que a norma não contemplava corretamente todos os titulares de direitos lesados. Se eram a parte e o Estado quem estavam sofrendo com a deslealdade processual, por que somente à primeira se contemplava o direito de exigir a punição? (IOCOHAMA, 2006, p. 81).
}

Atualmente, a redação do art. 81 do CPC/2015, permite ao juiz reconhecer de ofício a litigância de má-fé, todavia, a autorização do reconhecimento de ofício nesta perspectiva, serve para possibilitar que os juízes e tribunais, exerçam o controle dos atos dos sujeitos processuais, no sentido de que sejam praticados com obediência a finalidade contemporânea do processo.

Destarte, mesmo tendo origem no direito privado, o princípio da boa-fé previsto no art. $5^{\circ}$, caput do $\mathrm{CPC} / 2015$, para que cumpra sua função processual com máxima efetividade, não 
pode ser visto pelos juízes e tribunais como simples decorrência da boa- fé que rege o direito material. Assim, imperioso reconhecer que para o processo civil, a correta aplicação da boa-fé não pode se restringir as mesmas questões envolvendo o direito material.

A justificativa para tanto, reside no reconhecimento de que o processo possui natureza de direito público, tanto que ao tratar do princípio da boa-fé processual, a doutrina de J. E. Carreira Alvim discorre que a boa-fé deve ser observada como princípio impeditivo de utilização do processo "na contramão da justiça", o que possibilitaria, no seu entendimento, "chegar-se a resultados que não estejam de conformidade com a verdadeira situação de fato que empresta embasamento às pretensões das partes" (ALVIM, 2019, p. 255).

Dessa forma, não são as regras e princípios de direito privado que influenciarão o reconhecimento de atos violadores da boa-fé, mas sim, precipuamente, as finalidades do processo civil contemporâneo no Estado Social de Direito, pautado na busca de solução de litígios, voltados a realização dos direitos fundamentais.

\section{CONCLUSÃO}

A norma fundamental da boa-fé processual, prevista no Código de Processo Civil de 2015 (art. $5^{\circ}$, caput), constitui norma geral definidora de deveres comportamentais, norteadora da atuação das partes no processo civil, cuja interpretação mais consentânea, permite o reconhecimento de atos como litigância de má-fé, abusivos ou danosos, ainda que não tipificados expressamente, já que referido princípio detém força interpretativa, integradora e corretiva das demais normas do Código de Processo Civil.

Na esfera executiva, considerando que o exequente naturalmente se encontra em posição de superioridade em relação ao executado, o princípio da boa-fé deve ser estimulado, autorizando sua aplicação a situações abusivas praticadas pelo exequente, cuja intenção primordial, não objetiva a satisfação de seu direito, mas sim causar prejuízos em desfavor do executado.

Para que se possa conferir a máxima efetividade do princípio da boa-fé na esfera processual, necessário afastar-se da aplicação do mesmo princípio nas questões envolvendo o direito material, ou seja, imprescindível reconhecer que o processo possui natureza de direito público, e sob essa perspectiva, os atos dos sujeitos processuais devem obediência a finalidade contemporânea do processo. 
Dessa forma, não são as regras e princípios de direito privado que influenciarão o reconhecimento de atos violadores da boa-fé, mas sim, precipuamente, as finalidades do processo civil contemporâneo no Estado Social de Direito, pautado na busca de solução de litígios, voltados a realização dos direitos fundamentais.

Todavia, para que efetivamente seja aplicado todo o conteúdo do princípio da boa-fé processual, a atuação da jurisprudência deverá ser pautada no sentido de reconhecer a violação do aludido princípio, não apenas nos casos em que há tipificação de atos com a pecha de litigância de má-fé, atentatório a dignidade da justiça ou fraude à execução. Pelo contrário, deve-se reconhecer que se trata de norma com conteúdo geral, com autonomia para ensejar o reconhecimento de atos abusivos, ainda que não especificamente tipificados como litigância de má-fé e seus consectários.

\section{REFERÊNCIAS}

ALEXY, Robert. Teoria dos direitos fundamentais. Trad. Virgílio Afonso da Silva. 2. ed. São Paulo: Malheiros, 2017.

ALVIM, A. Manual de direito processual civil. 19. ed., ver., atual. e ampl. São Paulo: Thomson Reuters Brasil, 2020.

ALVIM, J. E. Carreira. Teoria geral do processo. 22. ed. Rio de Janeiro: Forense, 2019.

ANGHER, Anne Joyce. Litigância de má-fé no processo civil. São Paulo: Rideel, 2005.

ARAÚJO, F. C. de. Curso de processo civil: tomo I - parte geral. São Paulo: Malheiros, 2016.

BRASIL. Lei no 13.105, de 16 de março de 2015. Código de Processo Civil. Diário Oficial da União, Brasília, 17 mar. 2015. Disponível em: <

http://www.planalto.gov.br/ccivil_03/_ato2015-2018/2015/lei/113105.htm>. Acesso em: 01 set. 2020.

BRASIL. Superior Tribunal de Justiça. Agravo Interno no Recurso Especial n. 1644759. Diário de Justiça eletrônico: 30.06.2020. Disponível em:

https://ww2.stj.jus.br/processo/revista/inteiroteor/?num_registro=201603296606\&dt_pu blicacao=30/06/2020. Acesso em: 01 set. 2020 .

BRASIL. Superior Tribunal de Justiça. Recurso Ordinário em Habeas Corpus n. 97876. Diário de Justiça eletrônico: 09.08.2018. Disponível em: https://ww2.stj.jus.br/processo/revista/inteiroteor/?num_registro=201801040236\&dt_pu 
blicacao=09/08/2018. Acesso em: 01 set. 2020.

BUENO, Cassio Scarpinella. Curso sistematizado de direito processual civil. vol. 1. 10. ed. São Paulo: Saraiva, 2020.

CÂMARA, Alexandre Freitas. O novo processo civil. 6. ed. São Paulo: Atlas, 2020. CAMBI, Eduardo (et. al). Curso de processo civil completo. 2. ed. rev., atual. e ampl. São Paulo: Thomson Reuters Brasil, 2019.

CANOTILHO, J. J. Gomes. Direito constitucional e teoria da constituição. 7. ed. 21. reimp. Coimbra: Almedina, 2003.

COSTA, Fabrício Veiga. Princípios regentes do processo civil no Estado Democrático de Direito: ensaios de uma teoria geral do processo civil. Belo Horizonte: D’Placido, 2019.

DIDIER JR. Fredie. Curso de processo civil: introdução ao direito processual civil, parte geral e processo de conhecimento. v. 1. 19. ed. rev., ampl. e atual. Salvador: JusPodivm, 2017.

DIDIER JR. Fredie (et. al.). Curso de processo civil: execução. v. 5.7 ed. rev., ampl. e atual. Salvador: Ed. JusPodivm, 2017.

DINAMARCO, Cândido Rangel. Instituições de direito processual civil: volume II. 8. ed., rev. e atual. São Paulo: Malheiros.

IOCOHAMA, Celso Hiroshi. Litigância de má-fé e lealdade processual. Curitiba: Juruá, 2006.

MARINONI, Luiz Guilherme.; ARENHART, Sérgio Cruz.; MITIDIERO, Daniel. Manual de processo civil. 4. ed. rev., atual. e ampl. São Paulo: Thomson Reuters, 2019.

MEDINA, J. M. GARCIA. Curso de direito processual civil moderno. 5. ed. rev., atual. e ampl. São Paulo: Thomson Reuters Brasil, 2020.

MEDINA, J. M. GARCIA. Execução: teoria geral, princípios fundamentais, procedimento no processo civil brasileiro. 6. ed. rev., atual. e ampl. São Paulo: Thomson Reuters Brasil, 2019.

MITIDIERO, Daniel. Colaboração no processo civil: do modelo ao princípio. 4. ed. rev., atual. e ampl. São Paulo: Thomson Reuters Brasil, 2019.

PINTO, Christian Barros. Abuso processual: atuação contrária a jurisprudência e efetividade da jurisdição frente ao princípio cooperação processual. Belo Horizonte: D’Plácido, 2018.

SÃO PAULO. Tribunal de Justiça. Agravo de Instrumento: 2123237- 42.2020.8.26.0000. Relator: Francisco Loureiro. $1^{a}$ Câmara de Direito Privado. São Paulo, 9 jul. 2020. Disponível em: https://esaj.tjsp.jus.br/cjsg/getArquivo.do?cdAcordao=13735578\&cdForo=0. Acesso em: 1 set. 2020.

SÃO PAULO. Tribunal de Justiça. Apelação Cível: 0012761-02.2019.8.26.0001. Relatora: 
Maria de Lourdes Lopez Gil. $7^{\text {a }}$ Câmara de Direito Privado. São Paulo, 6 jul. 2020 (segredo de justiça).

SÃO PAULO. Tribunal de Justiça. Agravo de Instrumento: 2092667- 73.2020.8.26.0000.

Relator: Luiz Antonio de Godoy. $1^{a}$ Câmara de Direito Privado. São Paulo, 29 jun. 2020.

Disponível em: https://esaj.tjsp.jus.br/cjsg/getArquivo.do?cdAcordao=13696237\&cdForo=0.

Acesso em: 1 set. 2020.

SÃO PAULO. Tribunal de Justiça. Agravo de Instrumento: 2151065- 13.2020.8.26.0000.

Relator: Jayme de Oliveira. 29a Câmara de Direito Privado. São Paulo, 10 ago. 2020.

Disponível em: https://esaj.tjsp.jus.br/cjsg/getArquivo.do?cdAcordao=13841232\&cdForo=0.

Acesso em: 1 set. 2020.

SÃO PAULO. Tribunal de Justiça. Agravo de Instrumento: 2127473- 37.2020.8.26.0000.

Relator: Alexandre Coelho. $8^{\text {a }}$ Câmara de Direito Privado. São Paulo, 29 jun. 2020.

Disponível em: https://esaj.tjsp.jus.br/cjsg/getArquivo.do?cdAcordao=13695941\&cdForo=0.

Acesso em: 1 set. 2020.

VIANNA, José Ricardo Alvarez. Apontamentos sobre a litigância de má-fé no CPC/2015. Revista de Processo. vol. 280. ano 2018. p. 17-37. 